\title{
Management of post harvest pests of maize in India through enhanced hermetic storage
}

\author{
P. Lakshmi Soujanya*, J.C. SeKhar, G.K. ChikKapPA ${ }^{1}$ and P. KumaR ${ }^{1}$ \\ Winter Nursery Centre, ICAR-Indian Institute of Maize Research, Rajendranagar, HYDERABAD (A.P.) INDIA \\ Email : soujanyak.scientist@gmail.com \\ ${ }^{1}$ Directorate of Maize Research, Pusa Campus, NEW DELHI, INDIA
}

*Author for Correspondence

Research chronicle : Received : 04.12.2014; Revised : 20.04.2015; Accepted : 01.05.2015

\begin{abstract}
SUMMARY :
Effectiveness of hermetic storage in combination with botanical Ageratum conyzoides for the control of post harvest pests of maize Sitophilus oryzae (L.) and Sitotroga cerealella (Oliv.) was evaluated under artificial infestation by different packing materials. It was observed that High density polythene (HDPE) bag and Double Layered Polythene (DLP) bag with A. conyzoides are most effective in controlling $S$. oryzae and $S$. cerealella. The number of $\mathrm{F}_{1}$ progeny of $S$. oryzae and $S$. cerealella emerged in treatments ranged from 7.75 to 21.70 and 8.70 to 25.50 , respectively with each mean being significantly different from each other. Both HDPE and DLP bag in combination with A. conyzoides recorded lowest adult emergence, minimum grain damage and weight loss when infested by $S$. oryzae and S. cerealella. HDPE bag and double layered polythene bag with A. conyzoides recorded per cent damage of 4, 5.70 and 5.0, 7.0 and minimum losses of $0.61,0.94$ and $0.37,0.52$ by S. oryzae and $S$. cerealella, respectively. The results demonstrated that it is technically feasible to control post harvest pests of maize in India through enhanced hermetic storage by utilizing locally available botanicals.
\end{abstract}

KEY WORDS : Botanicals, Hermetic storage, Maize, Post harvest loss, Sitophilus oryzae, Sitotroga cerealella

How to cite this paper : Soujanya, P. Lakshmi, Sekhar, J.C., Chikkappa, G.K. and Kumar, P. (2015). Management of post harvest pests of maize in India through enhanced hermetic storage. Internat. J. Proc. \& Post Harvest Technol., 6 (1) : 48-53. 